\title{
Nuclear DNA Endoreduplication and Expression of the Mitotic Inhibitor Ccs52 Associated to Determinate and Lupinoid Nodule Organogenesis
}

\author{
Alfonso González-Sama, ${ }^{1,2}$ Teodoro Coba de la Peña, ${ }^{2}$ Zoltan Kevei, ${ }^{1}$ Peter Mergaert, ${ }^{1}$ \\ M. Mercedes Lucas, ${ }^{2}$ María R. de Felipe, ${ }^{2}$ Eva Kondorosi, ${ }^{1}$ and José J. Pueyo ${ }^{2}$ \\ ${ }^{1}$ Institut des Sciences du Végétal, Centre National de la Recherche Scientifique, Unité Propre de Recherche 2355, Avenue \\ de la Terrasse, 91198 Gif-sur-Yvette, France; ${ }^{2}$ Department of Plant Physiology and Ecology, Instituto de Recursos Naturales, \\ Centro de Ciencias Medioambientales, CSIC, Serrano 115-bis, E-28006 Madrid, Spain
}

Submitted 1 August 2005. Accepted 30 September 2005.

\begin{abstract}
Lotus japonicus determinate nodules differ greatly from indeterminate nodules in their organogenesis and morphological characteristics, whereas Lupinus albus lupinoid nodules share features of determinate and indeterminate nodules. The mitotic inhibitor Ces52A is essential for endoreduplication and ploidy-dependent cell enlargement during symbiotic cell differentiation in Medicago truncatula indeterminate nodules. $\operatorname{ccs} 52 \mathrm{~A}$ homolog genes were isolated from lupin and lotus nodules; the deduced Ccs52A proteins showed high sequence similarity with other Cdh-1-type activators of the anaphase-promoting complex and were grouped with A-type Ccs52 proteins from different plants. In lupin, ccs52A expression was restricted to the earlier stages of nodule development, whereas $\operatorname{ccs} 52 \mathrm{~A}$ transcripts accumulated in lotus nodule primordia and, to a lesser extent, in mature nodules. Nodule development in Lupinus albus involved a progressive increase in nuclear and cellular size and ploidy level; similarly, Lotus japonicus nodules contained polyploid nuclei and enlarged cells in the infected zone. Nevertheless, in situ hybridization experiments showed the highest $\operatorname{ccs} 52 \mathrm{~A}$ expression in the inner cortex cells of the lupin nodule primordium, probably associated to the increased size of these cells in mature nodules. In view of our results, Ccs52A-mediated endoreduplication appears to be a universal mechanism required for nodule cell differentiation during the establishment of nitrogen-fixing symbioses.
\end{abstract}

Additional keyword: polyploidy.

The formation of nitrogen-fixing root nodules requires a precise exchange of recognition signals (Hirsch 1992) that trigger a series of plant morphogenetic changes, including the repeated division of root cortical cells. Nodule organogenesis involves a complex plant cell differentiation program. Rhizobia penetrate the root cortex, invade nodule primordium cells, and eventually evolve inside infected cells to their nitrogen-fixing form, the bacteroid (Brewin 1991). Two main types of nodules can be distinguished according to the persistence of meristematic activity and the location of the first cell divisions in the

Corresponding author: J. J. Pueyo; Telephone: +34 917452500; Fax: +34 915640800; E-mail: pueyo@ccma.csic.es

Nucleotide sequence data is available in the GenBank database under accession numbers AY350619 for Llccs52A, AY350620 for Laccs52A, and DQ059035 for Ljccs52A. root cortex. Typical determinate nodules (lotus, soybean, common bean) are spherical, they develop from the outer cortex, and their meristematic activity ceases after a defined period of time. Characteristic indeterminate nodules (pea, alfalfa) are initiated in the inner cortex and have a cylindrical shape as a result of a persistent uninfected apical meristem. Nevertheless, certain nodule subtypes, such as aeschynomenoid nodules or lupinoid nodules, share features of determinate and indeterminate nodules (Sprent 2001).

A longitudinal section of a typical indeterminate nodule reveals cells at different stages of development, exhibiting a differentiation gradient from the apical part to the basal tissues attached to the root (Newcomb et al. 1979). The apical meristem is composed of small proliferating uninfected cells. In the prefixation zone, the symbiotic differentiation program involves cell division arrest, followed by several rounds of endoreduplication (endocycles) and cell enlargement. Enlarged polyploid cells are invaded and host the bacteroids, whereas small diploid cells remain uninfected. In the fixation zone, both the bacteria and the plant cells are differentiated for symbiotic nitrogenfixing activity (Truchet 1978).

Endoreduplication is a common phenomenon in developmental programs of plant polyploid organs and tissues (Kondorosi et al. 2000; Larkins et al. 2001) and is characterized by repeated S and Gap phases. In animals, endoreduplication is less common but is well-documented in salivary glands and Malpighian tubules of dipters and in the trochoblast, deciduas, and myocardial cells of mammals (Conlon and Raff 1999). During endocycles, nuclear DNA is replicated without mitosis or cytokinesis, resulting in cells with a DNA content greater than $2 \mathrm{C}$ ( $\mathrm{C}$ stands for the amount of DNA corresponding to the haploid complement). One way to induce endoreduplication is the inactivation of mitotic CDK/cyclin complexes before the M-phase transition point (Fang et al. 1998; King et al. 1995). This inhibition of mitosis, required for cell division arrest prior to differentiation, can be achieved by early activation of the anaphase promoting complex (APC) pathway, which is responsible for ubiquitin-dependent proteolysis of mitotic cyclins.

Two different genes encoding APC activators, $\operatorname{ccs} 52 \mathrm{~A}$ and $\operatorname{ccs} 52 \mathrm{~B}$, have been identified in Medicago truncatula and Arabidopsis thaliana (Cebolla et al. 1999; Tarayre et al. 2004). In Medicago truncatula, ccs52A is clearly responsible for mitotic cyclin degradation and for the regulation of endoreduplication during symbiotic cell differentiation in the indeterminate nodule. $\operatorname{ccs} 52 B$ is expressed in shoot apices but not in the symbiotic organ, indicating divergence in the expression patterns or 
functions, or both, of both homologs (Vinardell et al. 2003). $\operatorname{ccs} 52 \mathrm{~A}$ is not restricted to the nodulation process (Cebolla et al. 1999; Favery et al. 2002; Foucher and Kondorosi 2000; Koltai et al. 2001). In Medicago indeterminate nodules, $\operatorname{css} 52 \mathrm{~A}$ expression is localized in meristematic proliferating cells and in the prefixation zone differentiating cells, and its involvement has been established in nuclear DNA endoreduplication associated to nodule development (Cebolla et al. 1999; Vinardell et al. 2003).

Lotus japonicus was selected as a model legume to study determinate nodules. It is nodulated by Mesorhizobium loti and produces spherical nodules of finite development that originate from the outer cortex. The genus Lupinus establishes effective symbiosis with Bradyrhizobium sp. (Lupinus). Lupin nodules are recognized as a unique subtype of indeterminate nodules (Bergersen 1982). They are considered indeterminate because of their basi-lateral meristem, which can cause the nodule to grow until it surrounds the root. Growth often ceases earlier, however, and the nodule remains spherical, as for determinate nodules. Several other features distinguish lupinoid nodules from other nodule types: their initiation takes place in the outer cortex, the meristematic region contains bacteroids, the nodule does not show the typical zonation, and the infected central tissue does not have uninfected interstitial cells (Lotocka et al. 2000; Tang et al. 1992, 1993). Moreover, the infected zone originates from the division of a single infected cortical cell (González-Sama et al. 2004).

To acquire more insight into the development of determinate and lupinoid nodules and to verify the occurrence of Ccs52mediated endoreduplication, which may differ from that described in Medicago truncatula, we isolated and characterized $\operatorname{ccs} 52 \mathrm{~A}$ homologs from lotus and lupin and studied their role in the endoreduplication process triggered by rhizobial infection during establishment of nitrogen-fixing symbioses.
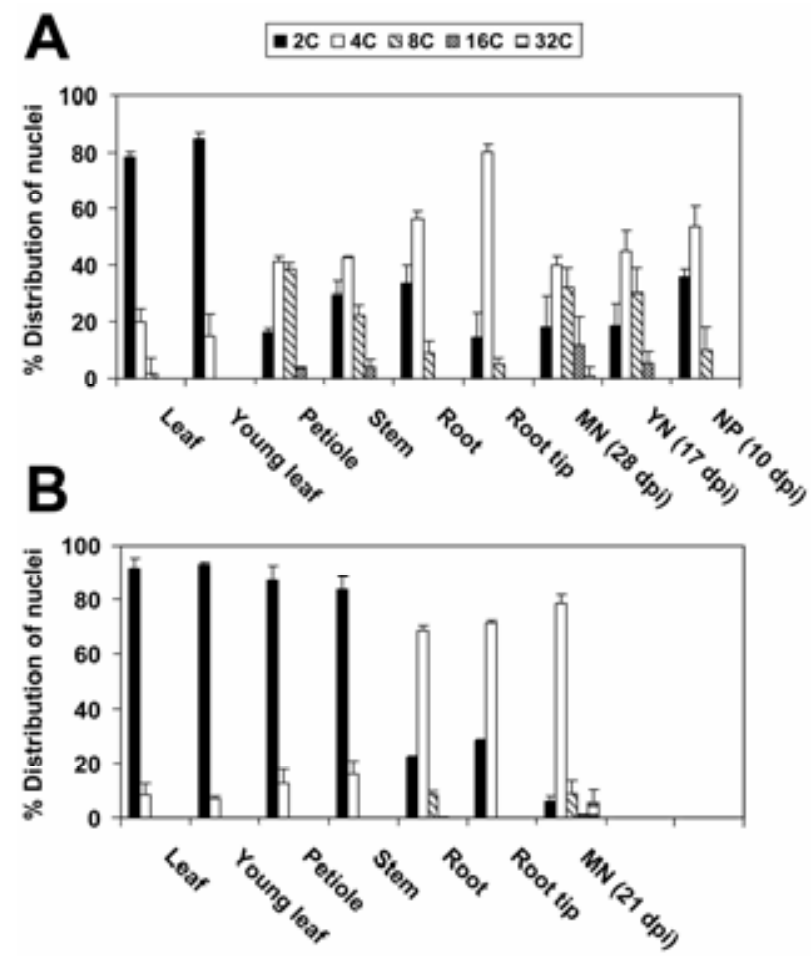

Fig. 1. Ploidy levels in A, Lupinus albus, and B, Lotus japonicus plants. Distribution (mean percentage) of nuclei with different DNA content in several organs. Standard error bars are displayed. NP = nodule primordium (10 days postinoculation [dpi]), YN = young nodule $(17 \mathrm{dpi}), \mathrm{MN}=$ mature nodule (28 dpi, lupin; 21 dpi, lotus).

\section{RESULTS}

Nodule development in Lupinus albus and

Lotus japonicus involves nuclear DNA endoreduplication.

The nuclear DNA content was measured in several organs at different developmental stages in lupin and lotus plants. The results showed a high diversity of ploidy levels in white lupin (Fig. 1A). All plant organs examined, except young leaves, contained polyploid nuclei with different levels of endopolyploidy. The highest degree of endoreduplication was detected in nodules (2C, $18 \%$; 4C, 38\%; 8C, 30\%; 16C, 13\%; 32C, 1\%) and petioles $(2 \mathrm{C}, 16 \% ; 4 \mathrm{C}, 42 \% ; 8 \mathrm{C}, 38 \% ; 16 \mathrm{C}, 4 \%)$. When comparing both legumes, higher levels of ploidy were observed in lupin for several organs (root tip, stem, petiole, and leaf). In lotus (Fig. 1B), roots (2C, 23\%; 4C, 68.8\%; 8C, 8\%; 16C, $0.2 \%$ ) and, specially, nodules $(2 \mathrm{C}, 6 \% ; 4 \mathrm{C}, 78 \% ; 8 \mathrm{C}, 9 \%$; $16 \mathrm{C}, 1 \% ; 32 \mathrm{C}, 6 \%$ ) were the only polyploid organs, and the polyploid nuclei distribution pattern differed from that found in lupin nodules.

Figure 2 shows the cellular and nuclear size in lotus nodules and in different stages of lupin nodule development, corresponding to the ploidy values (Fig. 1). Lupin nodule primordia (10 days postinoculation [dpi]) consisted of cells containing mainly $2 \mathrm{C}$ and $4 \mathrm{C}$ nuclei and a low proportion (approximately
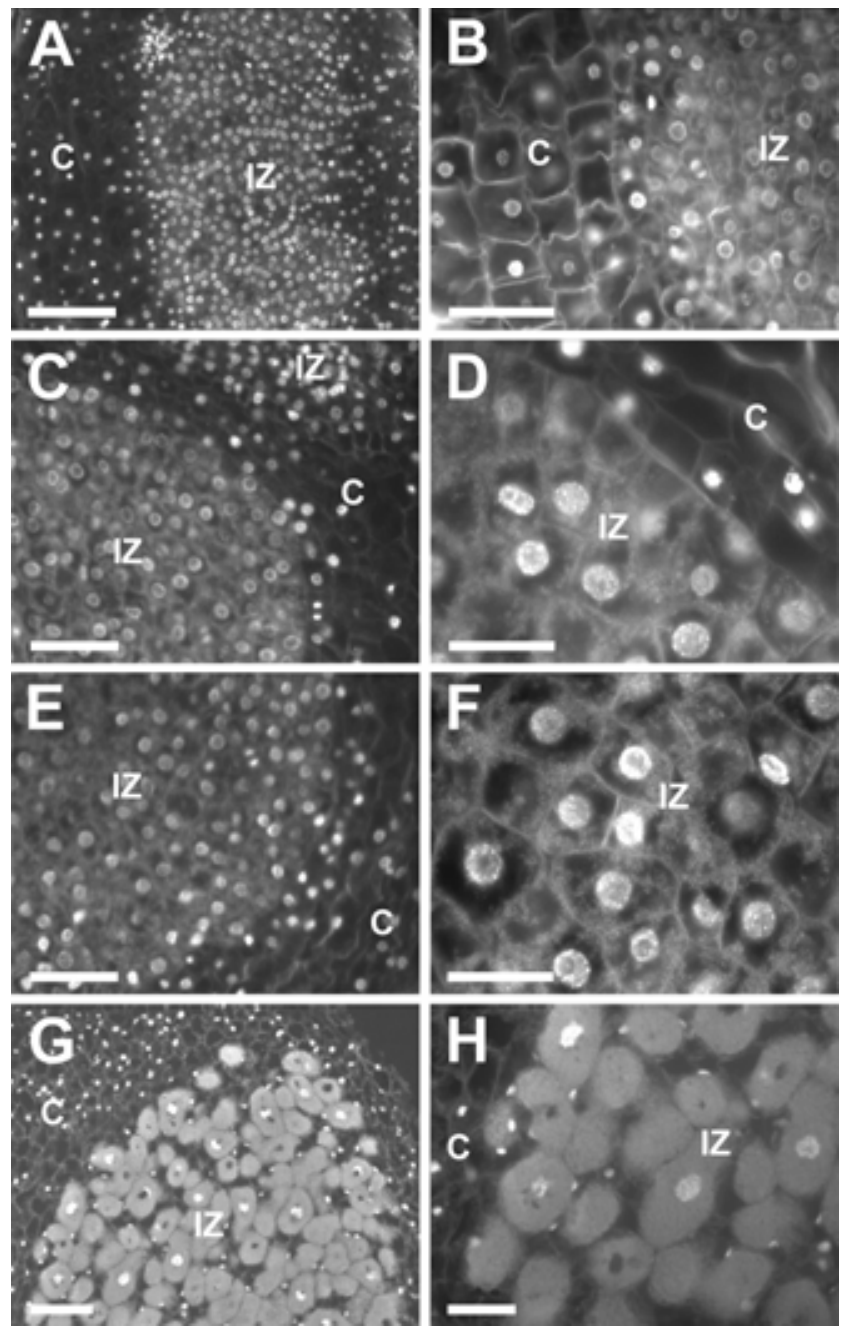

Fig. 2. Fluorescence micrographs showing nuclear and cell sizes. A and $\mathbf{B}$, Lupinus albus nodule primordia (10 days postinoculation [dpi]). $\mathbf{C}$ and $\mathbf{D}$, L. albus young nodules (17 dpi). E and F, L. albus mature nodules (28 dpi). $\mathbf{G}$ and $\mathbf{H}$, Lotus japonicus mature nodules (21 dpi). Nuclei were stained with 4',6-diamidino-2-phenylindol. $\mathrm{C}=$ cortex; IZ = infected zone. Scale bars $=100 \mu \mathrm{m}(\mathrm{A}, \mathrm{C}, \mathrm{E}$, and G) and $50 \mu \mathrm{m}(\mathrm{B}, \mathrm{D}, \mathrm{F}$, and H). 
$10 \%$ ) of polyploid cells with DNA contents greater than 4C. 2C and 4C nuclei may correspond to cells in the G1 and G2 cell cycle phases, respectively, and cells with $8 \mathrm{C}$ nuclei may be the result of a single endoreduplication event. The infected zone of the nodule primordium was composed of compacted cells with a nuclear size similar to that of the nodule cortex cells (Fig. 2A and B). Later in nodule development, young nodules (17 dpi) increased their ploidy level and 16C nuclei were detected, indicating that a new round of endoreduplication had taken place. Contents of polyploid cells $(>4 \mathrm{C})$ reached $36 \%$ of the total cell number. DAPI (4',6-diamidino-2phenylindol) staining showed a dramatic increase in nuclear and cell size in the infected zone relative to the previous developmental stage (Fig. 2C and D). Mature nodules (28 dpi) contained the highest proportion of cells with polyploid nuclei, accounting for $44 \%$ of total nuclei. An additional round of endoreduplication led to the appearance of a small group of cells with 32C nuclei (approximately 1\%). At this stage, nuclei and cells of the infected zone had reached maximum size (Fig. 2E and F).

A correlation could also be observed among nuclear size, cell size, and rhizobial infection in lotus nodules. DAPI staining of the nodule sections showed a clear difference between large infected cells with large nuclei and small noninfected cells with considerably smaller nuclear sizes (Fig. 2G and $\mathrm{H}$ ).

\section{Lupin and lotus have a $\operatorname{css} 52 A$ homolog.}

Since $\operatorname{css} 52 A$ is involved in the occurrence of endoreduplication cycles (endocycles) during the Medicago nodule differentiation program, we isolated the lupin and lotus $\operatorname{ccs} 52 \mathrm{~A}$ homologs.

Screening of a yellow lupin (Lupinus luteus) cDNA library, generated from developing root nodules, with a Medicago sativa $\operatorname{css} 52 \mathrm{~A}$ probe yielded a positive hybridization signal corresponding to a full-length cDNA clone $(2,076 \mathrm{bp})$, which coded for a 469-amino acid polypeptide. A full-length lotus cDNA clone was obtained by reverse transcription-polymerase chain reaction (RT-PCR) from nodule RNA. The clone contained an open reading frame encoding a polypeptide of 487 amino acids. Blastx searches to sequence databases showed that the isolated cDNA corresponded to $\operatorname{ccs} 52 \mathrm{~A}$ homologs, which we termed Llccs52A (GenBank accession number AY350619) and Ljccs52A (GenBank accession number DQ059035).

Alignment of L1Ccs52A and LjCcs52A with other known or putative plant $\mathrm{Ccs} 52 \mathrm{~A}$ and $\mathrm{Ccs} 52 \mathrm{~B}$ proteins revealed conservation among the different protein regions (Fig. 3A). The greatest divergence was found at the $\mathrm{N}$-terminal region, whereas the C-terminal region proved to be highly conserved. L1Ccs52A structure was very similar to that described for MsCcs52A and MtCcs52A (Cebolla et al. 1999; Tarayre et al. 2004). LlCcs52A and LjCcs52A bore a putative PEST motif at the Nterminal region and several putative CDK phosphorylation sites that might be involved in posttranscriptional regulation of the protein. The C-terminus had seven WD40 repeats. Moreover, the lupin and lotus homologs contained the C-box and CSM (Cdh1-specific motif) conserved motifs and the IR tail required for Ccs52A protein binding to APC.

We generated a phylogenetic analysis based on a multiple alignment with plant homologous proteins (Fig. 3B). The tree separates two major clusters corresponding to the A- and Btype Ccs52 proteins. LlCcs52A and LjCcs52A were grouped with the A-type Ccs52 proteins and, within them, with legume Ccs52A proteins. The phylogeny of the Ccs52A proteins follows the general phylogeny of the plant kingdom, indicating that these proteins are, indeed, Cdh1-type of APC activators and orthologs of the Medicago Ccs52 protein. ccs52 is expressed during Lupinus albus and Lotus japonicus nodule development.

To obtain a homologous probe for gene expression studies in white lupin nodule organogenesis, we isolated a partial cDNA clone from developing Lupinus albus (white lupin) nodules using RT-PCR. We cloned and sequenced a 1,368-bp cDNA product corresponding to the $\mathrm{N}$-terminal region and part of the WD40 repeats (GenBank accession number AY350620). This Lupinus albus Laccs $52 \mathrm{~A}$ fragment shared $98.5 \%$ amino acid identity with the corresponding region of Lupinus luteus Llccs52A, differing in only seven residues.

Northern blot and RT-PCR were used to elucidate the ccs52 temporal expression pattern in Lupinus albus and Lotus japonicus, respectively. For lupin (Fig. 4A), total RNA was isolated from the nodulation-competent zone of inoculated roots (7 dpi), nodule primordia (10 dpi), young nodules (17 dpi), mature nodules (28 dpi), and other plant organs (root tip, nodulation-competent zone of uninoculated roots, young leaf, mature leaf, and cotyledon). ccs52 mRNA was detected at very early stages of nodule development when nodule primordia are not yet visible on the root surface $(7 \mathrm{dpi})$; the highest expression levels were found in nodule primordia (10 dpi). Much lower expression was observed in young nodules (17 dpi), root tips, and uninoculated roots. In lotus, gene expression along nodule development was analyzed by RT-PCR (Fig. 4B) in inoculated roots, young nodules ( $7 \mathrm{dpi})$, and mature nodules (21 dpi). Ubiquitin was used as a constitutive control and leghemoglobin as an indicator of nodule development. The highest expression was also detected at the initial steps of development, in nodule primordia ( $7 \mathrm{dpi}$ ).

In situ hybridization experiments were performed on lupin nodule primordia (10 dpi) (Fig. 5). Sections were hybridized with $\operatorname{ccs} 52 a$ sense and antisense RNA probes. The sense probe yielded no hybridization signal above background level in negative controls. Transcripts were detected preferentially in the nodule inner cortex surrounding the infected zone, while we observed lower, uniform labeling in the infected zone.

\section{DISCUSSION}

As early as 1908, Fred noted that the mitotic figures in cells of the nodules of some fifty leguminous plants were "larger, very irregular and not well marked, with uneven number of chromosomes" as compared with root-tip cells (Fred 1908). Although polyploidy has been reported in determinate, indeterminate, and lupinoid nodules (Kodama 1970), studies of the endoreduplication process associated with nodule organogenesis have been carried out exclusively on Pisum, Medicago, and other indeterminate nodules. One important finding in these studies was the identification of the Ccs52A protein, a Cdh1type of APC activator, as a central regulator of endoreduplication and ploidy levels (Cebolla et al. 1999; Vinardell et al. 2003). Ccs52A promotes the exit of meristematic cells from the cell division cycle and their entrance into endoreduplication cycles via activation of ubiquitination-dependent proteolysis of mitotic cyclins (Cebolla et al. 1999). The importance of endoreduplication for normal symbiotic cell differentiation in nodules was demonstrated by manipulating $\operatorname{ccs} 52 \mathrm{~A}$ expression in transgenic plants (Vinardell et al. 2003). Here, we describe the isolation and molecular characterization of Ccs52A homologs from lupin and lotus and their participation in the increase in ploidy levels observed during nodule development. Lotus and lupin are models for determinate and lupinoid nodules, respectively, whose developmental processes exhibit distinct features.

Endoreduplication is a frequent phenomenon in plant organ development. The organ-specific but reproducible ploidy pattern in plants suggests that endoreduplication cycles are critical in 


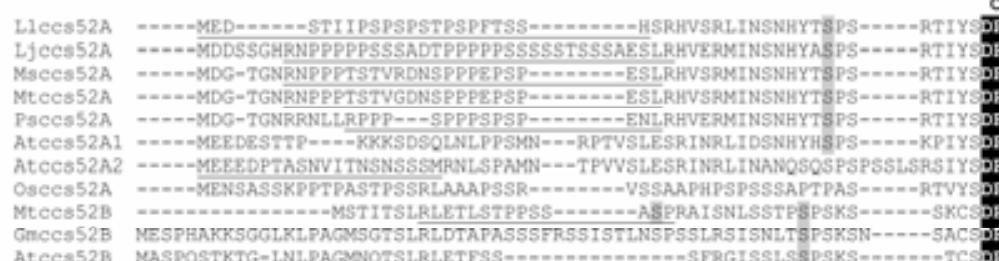

Atecs 528

CSM

L $1 \operatorname{ccs} 52 \mathrm{~A}$

Ljecs $52 \mathrm{~A}$

Ksccs $52 \mathrm{~A}$

Ntecs $52 \mathrm{~A}$

Psecs52A

Atecs52A1

Atces 52A2

Osces52A

Necess28

Atecs $52 \mathrm{~B}$

L1CCSS2A APRKVSPSPYK--

LjeCs52A TPRKVPRSPYK -

$\operatorname{Msccs} 52 \mathrm{~A}$

Ntcos $52 A$

TPRKVPRSPYK

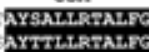

SNFALFDINSPETREDA-=SASNALFDINSSPETRPDA $=-\cdots$ ASKFALFDINTPTECRDDS $=\cdots$ SKFALFDINTPTEGRDDS $=-\cdots$ SKFALFDTNTTTECRDDS- SSNFALFDLASSSPQYKXPGYEDC SWEALEDISPIEPS--KDGKED GSWHAFDLAPSPSHDAAAAAA

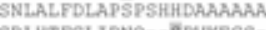

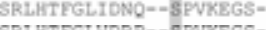
SRLHAFDLOOKEPTIPVKEGG-

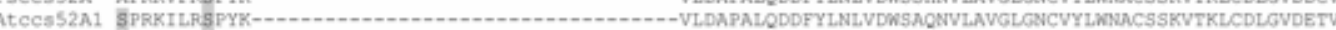
AtCeS52A2 APRKVPRSPYKILDLVDFRSLVS MHETICDLCDVLVSEGLEEESEVLDAPALODDFYLNLVDWSAOWVLAVGLGNCVYLWNACSSKVTKLCDLGAEDSY

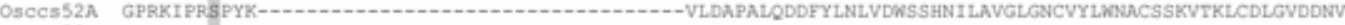
NtcCSS2B PPRKVPKTPHK-GnCCSS2B PPRKVPKTPHK----Atccs52 B pPPKYPKTPHK--------

$\operatorname{Liccs} 2 \pi$

$4 \cos 22 A$

vocoss

Ntcess $2 A$

pecs $52 A$

atccs52A1

Atccos $2 \mathrm{~A} 2$

Oscess2 2

Stccos2 2 B

Gnces52D

Atces $\$ 2 \mathrm{~B}$

$\operatorname{Liccs} 52 \mathrm{~A}$

$L j \cos 2 \mathrm{~A}$
$\mathrm{Mec} \cos 2 \mathrm{~A}$

$\mathrm{MtCC}=52 \mathrm{~A}$

Pecess 2 A

Atecs52A

Atces $52 \mathrm{Az} 2$

Osecs52A

Orces $52 B$

Atecs 521

$L 1 \cos 52 A$

Lject52A

$\operatorname{Msccs} 52 A$

Necos 2 a

Atcess $2 \mathrm{~A} 1$

Atcess2A1

Atecs $22 \mathrm{~A} 2$

Osccss2A

Ntccss2

Ancess2B

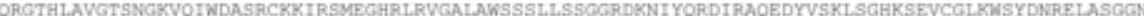

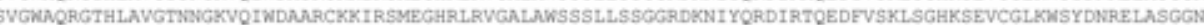

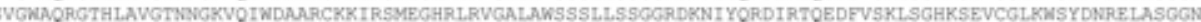

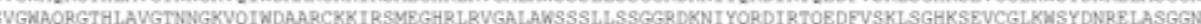

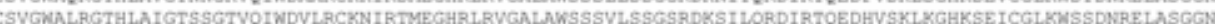
CSVGWALRGTHLAVGTSTOKVOTWDASRCKRTRTMEGHRLRVGALAWGSSVLSSGSPDKSILORDIRCOEDHVSKLAGHKSEVCOLKWSYDNREIASGGN CSWGWAQRGTHLAWGTNQGKVQWWDATACKRIRTMESHRNRVGALAWNSSLLSSGSRDKSI LHHDIRAQDDYISRLAGHKSEVCGL.KWSYDNRQLASGGN

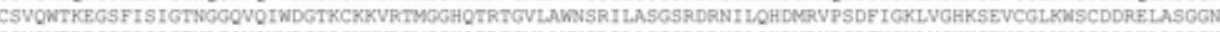
CSWOWTREGSFISIGTNLGOVOWWDGTCKXVRTMGGHOTRTGVLAWNSRILASGSNDNWILOHDNRVPGDEVSKLVGEKSEVCGLKWSCDDRELASGGI

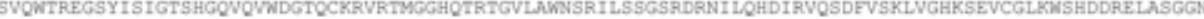

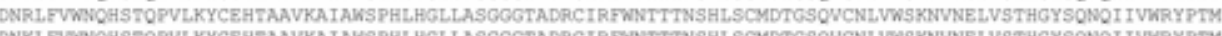
OWKLFVWNOHSTOPVLKYCEHTAAVKAIAWSPHLHGLLASGGGTADRCIRFWNTTTNSHLSCMDTGSOWCNLVWSKNWNELVSTHGYSONOIIVWRYPTM DNKLFVWNOHSTOPVLKYCEHIMAVKAIAWSPHLHGLLASGGGTADRCIRFWNTTTNSHLSCMDTGSOWCNLVWSKNVNELVSTHGYSONOI IVWRYPTM DNKL.FVWNOHSTOPVLKYCEHTAAVKAIAWSPHLHGLLASGGGTADRCIRFWNTTTNSHLSCMDTGSOWCNLVWSKNWNELVSTHGYSONOI IVWRYPTY DNKLEVWVGSTQPVLRFCEHAAAVKAIAKSPHAFGLLASGGGTADRCIRFWNTTTNTHLNCVDTNSOWCNLVWSKNVNELVSTHGYSONQIIVKKYPTM

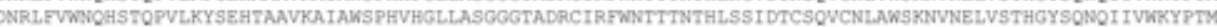

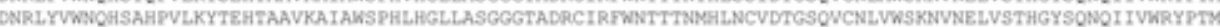

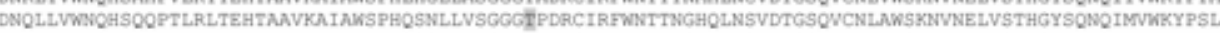
DNOLLVWNQHSOOPVLRLTEHYAAVKAIAWSPHOSSLLVSCGGTADRCIRFWNTTNGHOLNCVDTGSOWCNLAWSKNVNELVSTHGYSONOTMVWKYPSL

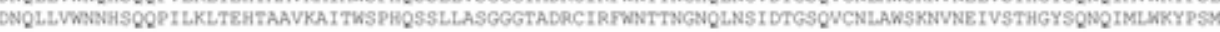

SKL.ATLTCHTYRVLYLAISPDCOTIVTCGACDETLRFWNVFPSPKSONSD--TEICASSLGRTTIR SKLATLTGHTYRVLYLAISPDGOTIVTGAGDETLRFWNVPFPKSONTD--SEIGRSSLGRTIIR

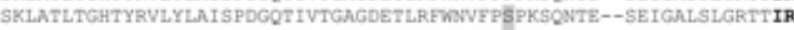
SKLATLTCHTYRVLYLAISPDCOTIVTGAGDETLRFWNVFPSPKSONTE--SEIGALSLGRTTIA SKLATLKGHTYRVLYLAISPDGOTIVTGAGDETLRFWNVFPSPKSCNTE--SEICALSLGRTTIR SKL.ATLTCHSYRYLYLAVSPDCOTIVTCACDETLRFWNVPSPKSOSRE--SETCALSFGRTTIR SKIATLTGHTYRVLYLAVSPDCOTIVTCACDETLRFXNVFPSPKSONTD--SEIGSSFYGRTTIR

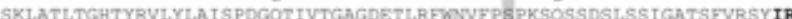

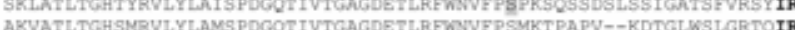

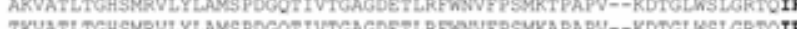
SKVATLTGHSMRVLYLATSPDCOTIVTGAGDETLRFWWVPSVKYOTPV--KDTGLWSIGRTOIR

B

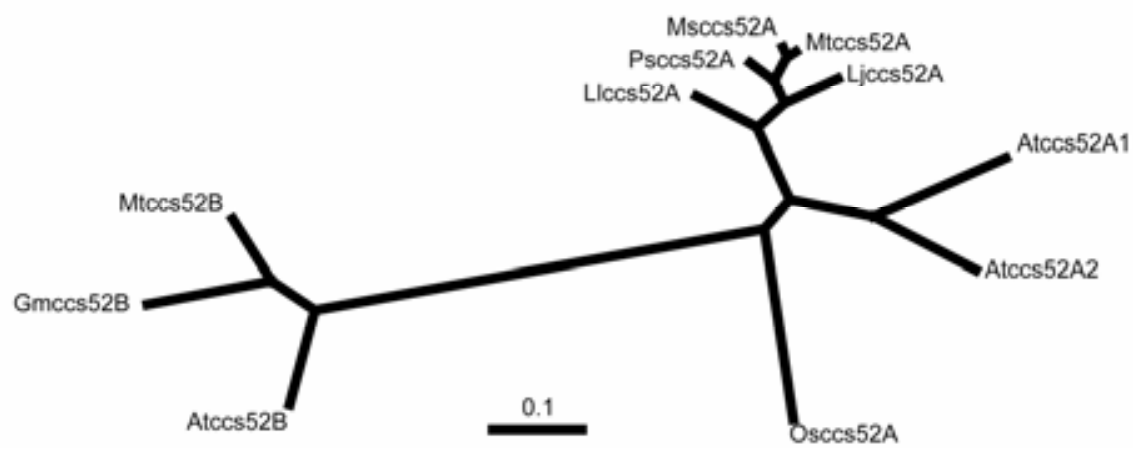

Fig. 3. Sequence analysis of Lupinus luteus and Lotus japonicus Ccs52A homologs. A, Multiple alignment (Clustal W) of the amino acid sequence of plant Ccs52A proteins. Conserved sequences (C-box and CSM) are indicated on black-shaded background and WD40 repeats with double arrows. Putative PEST motifs are underlined, and S and T residues of putative CDK phosphorylation sites are gray-shaded. IR tail is indicated in bold type. $\mathbf{B}$, Phylogenetic analysis of plant Ccs52A proteins. The unrooted tree was constructed with the PHYLIP program (Felstein 1989) from multiple alignment Clustal W. At $=$ Arabidopsis thaliana, $\mathrm{Gm}=$ Glycine max, $\mathrm{Lj}=$ Lotus japonicus, $\mathrm{Ll}=$ Lupinus luteus, $\mathrm{Ms}=$ Medicago sativa, $\mathrm{Mt}=$ Medicago truncatula, $\mathrm{Ps}=$ Pisum sativum, Os $=$ Oryza sativa. Sequence accession numbers are (in order of alignment) AY350619, DQ059035, AF079404, AF134835, DQ059036, AY128834, AY091235, AP003298, AY357299, AI736659, and AY099581. 
differentiation programs (Grafi 1998). In Lupinus albus and Lotus japonicus, different levels of DNA content were detected, depending on the tissue and organ tested, but the highest endopolyploidy was found in mature nodules, as reported in Medicago plants (Cebolla et al. 1999). Comparison of ploidy levels in different organs nonetheless evidences variations in the distribution patterns and in the DNA content of polyploid nuclei, suggesting different requirements for endopolyploidy in each legume. The percentage of polyploid nuclei (greater than 4C) in lupin petioles $(42 \%)$ is double that of Medicago petioles (20\%), although 32C nuclei, absent in lupin petioles, are present in Medicago petioles. In contrast, no polyploid nuclei are detected in lotus petioles. Nodules were characterized by a high level of endopolyploidy in the three legumes, although there were differences among them. Medicago (Cebolla et al. 1999 ) and lotus nodules have a large proportion of 32C nuclei (11\% and 6\%, respectively) compared with lupin nodules (approximately $1 \%$ ), although the total percentage of polyploid nuclei $(>4 \mathrm{C})$ in the latter is much higher $(44 \%)$ than in Medicago (24\%) or Lotus (approximately 16\%). These differences in distribution and content of polyploid nuclei might be the result of distinct nodule developmental programs. During Medicago and Lotus nodule development, the diploid meristematic cells cease to divide, enter the differentiation program, are infected by rhizobia, and undergo endoreduplication. During lupin nodule development, however, plant cells are infected first and the processes of cell division and symbiotic differentiation take place afterwards (González-Sama et al. 2004).

Comparison of the LlCcs52A and LjCcs52A sequences with the protein databases indicated that the lupin and lotus homologs share high similarity with Ccs52-type APC activators. Phylogenetic analysis showed that LlCcs52A and LjCcs52A are grouped in the same branch with other Ccs52A proteins and are clearly distinct from the Ccs52B proteins. Phylogeny of the Ccs52A proteins follows that of the plant kingdom, suggesting that the LlCcs52A and LjCcs52A proteins are orthologs of the Medicago Ccs52 protein and that they are involved in

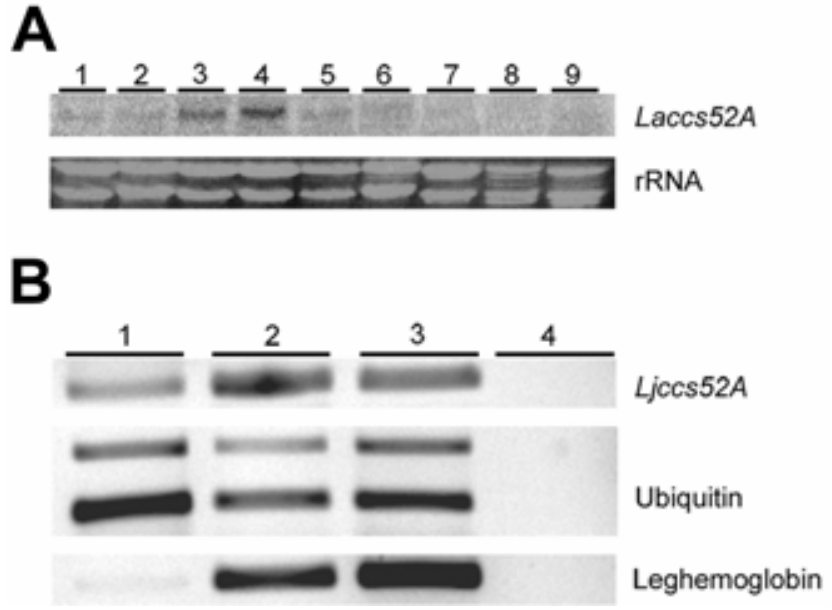

Fig. 4. Analysis of ccs52A expression in Lupinus albus and Lotus japonicus. A, ccs52A expression in Lupinus albus organs as analyzed by Northern blot. Lane 1, root tip; lane 2, nodulation-competent zone of uninoculated root; lane 3, nodulation-competent zone of inoculated root (7 days postinoculation [dpi]); lane 4 , nodule primordium (10 dpi); lane 5 , young nodule (17 dpi); lane 6, mature nodule (28 dpi); lane 7, young leaf; lane 8, mature leaf; and lane 9, cotyledon. Ethidium bromide-staining of rRNA was used to ensure equal RNA loading. B, Analysis of $\operatorname{ccs} 52 \mathrm{~A}$ expression in Lotus japonicus as analyzed by reverse transcriptionpolymerase chain reaction. Lane 1, nodulation-competent zone of uninoculated root; lane 2 , young nodule ( $7 \mathrm{dpi}$ ); lane 3 , mature nodule (21 dpi); and lane 4, water control. Ubiquitin was used as a constitutive control and leghemoglobin as an indicator of nodule development. control of endoreduplication during nodule development, as described for Medicago truncatula MtCcs52A (Vinardell et al. 2003). LlCcs52A and LjCcs52A contain motifs and amino acid residues involved in the protein function, such as a putative PEST motif for protein degradation and several CDK-phosphorylation sites, as well as the C-box and CSM motifs involved in interaction with other proteins, the seven WD40 repeats, and the IR tail (Tarayre et al. 2004).

Southern blot analysis (not shown) suggested that the lupin genome has at least two ccs52 homologs, as described in other plants such as Medicago truncatula and Arabidopsis (Tarayre et al. 2004). The sequence divergence between the $\operatorname{ccs} 52 \mathrm{~A}$ and $\operatorname{ccs} 52 B$ homologs and their distinct expression patterns indicate that they might participate in different developmental processes (Tarayre et al. 2004). The nature and function of putative $\operatorname{ccs} 52 B$ homologs in lupin and lotus remain to be studied.

During organogenesis of nitrogen-fixing nodules in Medicago truncatula, Mtccs52A expression is not detected during nodule initiation. It is switched on in the central region of the nodule primordium just before cell differentiation starts, and is maintained in the meristematic and prefixation zones of mature nodules (Cebolla et al. 1999; Vinardell et al. 2003). Conversely, in Lupinus albus, Llccs52A expression can be detected during the earliest steps of nodule organogenesis, when the nodule primordium is essentially constituted by a few small proliferating cells inside the root cortex; maximum expression is reached in freshly emerging nodule primordia. In both types of nodules, no expression is detected in the fully-differentiated nitrogen-fixing symbiotic cells. In lotus, highest expression occurs in very young nodules, but transcript accumulation is also detected in mature nitrogen-fixing nodules.

In situ hybridization experiments showed the highest expression levels in the inner cortex of the lupin nodule primordium, in a cell layer that will give rise to a cortex zone in the mature nodule. This cortex layer is composed of enlarged cells with thickened walls and broad intercellular spaces, a special feature of the lupin nodule cortex that has been related to the oxygen diffusion barrier (Iannetta et al. 1993). The very early Llccs $52 A$ expression in inoculated roots could be indicative of polyploid cell formation prior to infection, such that only polyploid cells would be infected by rhizobia, which also appears to be the case in Medicago truncatula nodules (Cebolla et al. 1999). In lupin nodules, the infected zone originates from the repeated division of a single infected cell (González-Sama et al., 2004).

Our results show that the $\operatorname{ccs} 52 \mathrm{~A}$ gene has a role in endoreduplication associated to nitrogen-fixing symbiosis that is widespread and independent of the nature of the nodule morphogenesis and differentiation program.

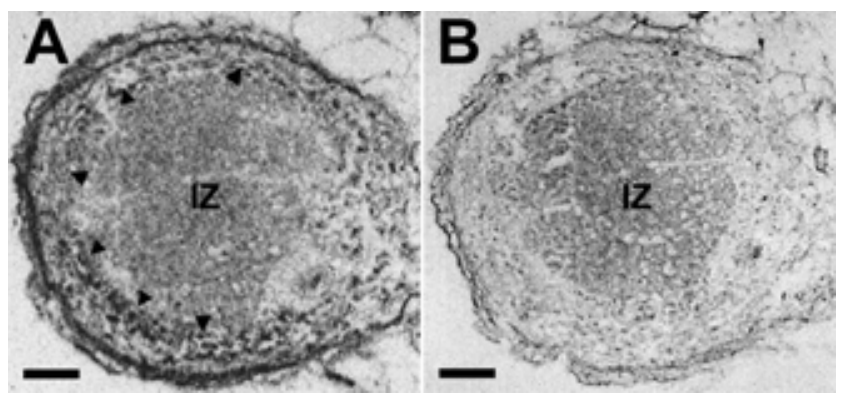

Fig. 5. In situ localization of Laccs52A transcripts in lupin nodule primordia. A, Nodule primordium section (10 days postinoculation) hybridized with an antisense probe. Arrowheads indicate the accumulation of transcripts in the inner cortex. B, Control hybridization with a sense probe. $\mathrm{C}=$ cortex, $\mathrm{VB}=$ vascular bundles, and $\mathrm{IZ}=$ infected zone. Scale bars $=100 \mu \mathrm{m}$. 


\section{MATERIALS AND METHODS}

Bacterial strain, plant material, and growth conditions.

Bradyrhizobium sp. (Lupinus) ISLU16 and Mesorhizobium loti MAFF303099 were grown at $28^{\circ} \mathrm{C}$ with gentle shaking in a yeast extract-mannitol liquid medium (Vincent 1970).

White lupin (Lupinus albus L. cv. Multolupa) seeds were surface-sterilized in $1 \% \mathrm{HgCl}_{2}$ with gentle shaking for $5 \mathrm{~min}$, were rinsed several times in distilled water, and were allowed to imbibe for $2 \mathrm{~h}$. Seeds were sown in pots containing sterilized vermiculite and were inoculated with $1 \mathrm{ml}$ of bacterial inoculum. Plants were grown in a growth chamber under controlled conditions at $60 \%$ relative humidity, $25^{\circ} \mathrm{C}$ day and $15^{\circ} \mathrm{C}$ night temperatures, and 16-h light photoperiod $(250 \mu \mathrm{mol}$ photon $\mathrm{m}^{-2} \mathrm{~s}^{-1}$ ). Plants were watered with distilled water for one week, with nitrogen-free nutrient solution (Hoagland and Arnon 1938) at one-fourth and one-half strength during the second and third weeks, respectively, and with undiluted Hoagland solution thereafter.

Seeds of Lotus japonicus Miyakojima MG20 were surfacesterilized with sulphuric acid for $15 \mathrm{~min}$, followed by thorough washing with water. Seeds were germinated on humidified Whatman paper, and seedlings were planted in pots containing perlite imbibed in nitrogen-poor growth medium (Solution I; EMBO Practical Course on the new plant model system Medicago truncatula website). Plants were grown in a growth chamber with a $16-\mathrm{h}$ photoperiod at $24^{\circ} \mathrm{C}$ day and $17^{\circ} \mathrm{C}$ night temperatures, $50 \%$ humidity, and regular watering with Solution I. One week after planting, plantlets were inoculated with approximately $1 \mathrm{ml}$ of a Mesorhizobium loti suspension at $\mathrm{OD}_{600}=0.1$ per plant.

\section{Flow cytometry analysis.}

DNA content of nuclei from different organs was determined by flow cytometry as described (Coba de la Peña and Brown 2001). Freshly collected plant material was finely cut with a razor blade in Galbraith buffer containing $0.1 \%$ Triton $\mathrm{X}-100$ and $0.1 \% \beta$-mercaptoethanol to release intact nuclei, as described previously (Galbraith et al. 1983). Isolated nuclei were filtered through $30-\mu \mathrm{m}$ nylon mesh and were stained with $5 \mu \mathrm{g} \mathrm{ml}{ }^{-1}$ 4',6-diamidino-2-phenylindole (DAPI) (Sigma Chemical Co., St. Louis). DNA histograms were generated by analyzing at least 5,000 nuclei per measurement in a minimum of three independent experiments, using an EPICS V flow cytometer (Beckman-Coulter, Roissy, France).

\section{Fluorescence microscopy.}

Nodule primordia and nodules of lupin and lotus at different stages of development were collected, fixed immediately at room temperature in FAA solution (3.7\% formaldehyde, $50 \%$ ethanol, and $10 \%$ acetic acid), and were stored overnight, dehydrated in an ethanol dilution series and embedded in Paraplast (Sigma) as described by McKhann and Hirsch (1993). Sections $(10 \mu \mathrm{m})$ were obtained from sample tissues. Paraffin was removed by xylene treatment, and tissue was rehydrated. Nuclei were stained with $1 \mu \mathrm{g}$ of DAPI containing $0.1 \%$ Triton $\mathrm{X}-100$ per milliliter, and cell walls were stained with $0.3 \mathrm{mg}$ of calcofluor per milliliter (Sigma). After washing with phosphate buffered saline, $\mathrm{pH}$ 7.2, sections were observed and photographed using a Zeiss Axioplan photomicroscope and UV light excitation.

\section{Isolation of $\operatorname{ccs} 52 A$ cDNA clones.}

A cDNA library of yellow lupin developing nodules constructed into the $\lambda$ UniZAP XR cloning vector (Stratagene, La Jolla, CA, U.S.A.) and containing approximately $4.4 \times 10^{10}$ $\mathrm{CFU} \mathrm{ml}{ }^{-1}$ was screened onto nylon filters (Biotrans, ICN Bio- medicals, Costa Mesa, CA, U.S.A.) by standard procedures (Sambrook et al. 1989). A random-primed ${ }^{32} \mathrm{P}$-labeled probe was generated using the Medicago sativa ccs52A cDNA as a template with the Megaprime DNA labeling kit (Amersham Pharmacia, Buckinghamshire, U.K.), according to manufacturer's instructions. Two rounds of screening were performed to obtain single positive clones. Phagemids were excised from $\lambda$ UniZAP to the plasmid form following manufacturer's instructions. Plasmid DNA was isolated according to standard procedures (Sambrook et al. 1989), and the insert was sequenced.

cDNA was prepared from $1 \mu \mathrm{g}$ of total RNA from white lupin young nodules using the First strand cDNA synthesis kit (Roche, Branchburg, NJ, U.S.A.) for RT-PCR, according to manufacturer's protocols. One-tenth of the RT reaction volume was used for PCR. Oligonucleotide design was based on the Llccs52A cDNA sequence (forward primer, 5'-CGATTATTCC TTCTCCTTCTCC- $3^{\prime}$ and reverse primer, $5^{\prime}$-ATGCTCCGATT TCAGTGTCC-3'). The PCR reaction consisted of 35 cycles $\left(30 \mathrm{~s}\right.$ at $95^{\circ} \mathrm{C}, 45 \mathrm{~s}$ at $55^{\circ} \mathrm{C}$, and $1 \mathrm{~min}$ at $72^{\circ} \mathrm{C}$ ) and an extension time of $10 \mathrm{~min}$ at $72^{\circ} \mathrm{C}$. The PCR product $(1,368 \mathrm{bp})$ was cloned into a pDrive cloning vector (Qiagen, Hilden, Germany) according to manufacturer's instructions. After cloning, the Laccs $52 A$ cDNA partial clone was confirmed by sequencing.

cDNA was prepared from $3 \mu \mathrm{g}$ of Lotus japonicus and $P$. sativum nodule total RNA with the PowerScript reverse transcriptase (BD Biosciences, Palo Alto, CA, U.S.A.), according to manufacturer's guidelines. Psccs52A cDNA was PCR-amplified with oligonucleotides based on the Mtccs52A sequence (forward primer, 5'-ATGGACGGAACCGGTAACCG and reverse primer, 5'-TCACCTAATAGTAGTTCTTCC). Ljccs52A cDNA was obtained by PCR, using primers designed on the basis of available EST sequences (accessions BI420244, AU252139, CB828401, BP061405, and BP034390). Primer sequences were 5'-ATGGACGATTCTTCCGGCC, 5'-GACA CCTCCAGCGCCTACACCACT, 5'-GAATCCG AGCCCCGT CAAGACT, 5'-AGTCTTGACGGGGCTCGGATTC, 5'-TGG TGGCCGGGAT AAGAATA, 5'-TATTCTTATCCCGGCCAC CA, 5'-CCACCCCCAGATGCAAGAAG TCCA, and 5'-TCA CCTTATAATAGTTCTTCC.

\section{Gene expression analysis.}

c cs52A expression in lupin was studied by Northern blot analysis. RNA was isolated by phenol extraction and $\mathrm{LiCl}$ precipitation as described (Goormachtig et al. 1995). Total RNA samples $(20 \mu \mathrm{g})$ were denatured in formamide/formaldehyde by heating $\left(65^{\circ} \mathrm{C}, 5 \mathrm{~min}\right)$ and then were separated electrophoretically on a $1.2 \%$ agarose gel containing formaldehyde. The presence of equal amounts of different RNA samples was confirmed by ethidium bromide staining. RNA was transferred to Hybond $\mathrm{N}$ membrane (Amersham Pharmacia Biotech) as described previously (Sambrook et al., 1989). RNA was fixed to the membrane by UV irradiation. Probes were ${ }^{32} \mathrm{P}$-labeled by random priming (Megaprime DNA labeling kit), using the 1,368-bp fragment of Laccs $52 A$ cDNA as template. Hybridization was performed overnight at $65^{\circ} \mathrm{C}$ in Rapid Hyb buffer (Amersham Pharmacia Biotech). Three 15-min washes were performed consecutively in $2 \times \mathrm{SSC}(1 \times \mathrm{SSC}$ is $0.15 \mathrm{M} \mathrm{NaCl}$ plus $0.015 \mathrm{M}$ sodium citrate), $0.5 \times \mathrm{SSC}$, and $0.1 \times \mathrm{SCC}$, containing $0.1 \%$ SDS, at $65^{\circ} \mathrm{C}$. Hybridization signals were visualized with a PhosphorImager (Molecular Dynamics, Sunnyvale, CA, U.S.A.).

Expression analysis in lotus was performed by semiquantitative RT-PCR. cDNA was prepared from $3 \mu \mathrm{g}$ of root, young (7 dpi) nodule, or mature (21 dpi) nodule total RNA with the PowerScript reverse transcriptase (BD Biosciences) according to manufacturer's instructions. For each semiquantitative PCR 
reaction, one two hundredth of the cDNA samples was used. Standard PCR conditions were used with 28 cycles for amplification of the ubiquitin and leghemoglobin fragments and 35 cycles for the ccs52A fragment. PCR products were analyzed on standard agarose gels. The primers were: for ubiquitin, forward primer, 5'-CTACAACATTCAGAAGGAGTCCA and reverse primer, 5'-CACAGGCCAG AAGAGGCCACAACA; for leghemoglobin, forward primer, 5'-GTTCTACACCGTTATAT TGGAGATAG and reverse primer, 5'-GCAGGGCTTCTTTAA CCACCACG; and for ccs52A, forward primer, 5'-TGGTGGC CGGGATAAGAATA and reverse primer, 5'-CCACCCCCAG ATGCAAGAAGTCCA.

\section{In situ hybridization.}

${ }^{35} \mathrm{~S}$-labeled sense and antisense probes were prepared by in vitro transcription with T7 polymerase (SP6/T7 DIG-RNA labeling kit; Roche) from linearized plasmid containing the 1,368-bp Lupinus albus ccs52a cDNA insert cloned in both orientations. The probes were hydrolyzed by alkaline treatment (carbonate buffer, $\mathrm{pH} 10.2$, at $60^{\circ} \mathrm{C}$ for $38 \mathrm{~min}$ ) to generate approximately 200 -bp fragments.

Nodule primordia and nodules at different stages of development were fixed immediately at room temperature in FAA solution and were stored overnight, dehydrated in an ethanol dilution series and embedded in Paraplast. Sections $(8 \mu \mathrm{m})$ of each tissue were mounted on Superfrost*/Plus slides (MenzelGlaser, Braunschweig, Germany). Immediately before hybridization, paraffin was removed by xylene treatment and tissue was rehydrated. Probe penetration was increased by the treatment of sections with proteinase $\mathrm{K}(1 \mu \mathrm{g} / \mathrm{ml})$ for $30 \mathrm{~min}$ at $37^{\circ} \mathrm{C}$.

Hybridization was performed overnight at $42^{\circ} \mathrm{C}$ in hybridization buffer (50\% deionized formamide, $0.3 \mathrm{M} \mathrm{NaCl}, 10 \mathrm{mM}$ Tris- $\mathrm{HCl}, 1 \mathrm{mM}$ EDTA, $1 \times$ Denhardt's solution, $10 \%$ dextran sulphate, $70 \mathrm{mM}$ dithiothreitol (DTT), 40 units of RNase inhibitor per milliliter, and $150 \mu \mathrm{g}$ tRNA/ml). The corresponding sense probe was used as negative control. After hybridization, sections were washed for $1 \mathrm{~h}$ in $2 \times$ SSC containing 10 $\mathrm{mM}$ DTT at room temperature and for $1 \mathrm{~h}$ in $0.1 \times \mathrm{SSC}$ containing deionized formamide and $10 \mathrm{mM}$ DTT at $47^{\circ} \mathrm{C}$. Sections were stained with $0.01 \%$ toluidine blue. Observations were made and photographs obtained with an epifluorescence Reichert Polyvar microscope. Radioactive in situ hybridization images were obtained with a combination of dark-field and epifluorescence illumination.

\section{ACKNOWLEDGMENTS}

The authors thank A. G. Legocki for kindly providing the yellow lupin cDNA library. S. Brown and O. Catrice (Institute des Sciences du Végétal) are acknowledged for the cytometry analysis. We thank C. Mark for editorial assistance. This work was supported by Ministerio de Ciencia y Tecnología (MCYT) grants BIO2001-2355 to M. R. de Felipe and AGL20012093 to J. J. Pueyo. A. Gónzález-Sama was a recipient of a MCYT predoctoral fellowship. T. C. de la Peña was a recipient of a Comunidad de Madrid postdoctoral fellowship and an I3P contract from Consejo Superior de Investigaciones Científicas.

\section{LITERATURE CITED}

Bergersen, F. J. 1982. Anatomy and structure of nodules. Pages 23-50 in: Root Nodules of Legumes: Structure and Functions. Research Studies Press, Chichester, U.K.

Brewin, N. J. 1991. Development of the legume root nodule. Annu. Rev. Cell. Biol. 7:191-226.

Cebolla, A., Vinardell, J. M., Kiss, E., Oláh, B., Roudier, F., Kondorosi, A., and Kondorosi, E. 1999. The mitotic inhibitor ccs52 is required for endoreduplication and ploidy-dependent cell enlargement in plants. EMBO (Eur. Mol. Biol. Organ.) J. 18:4476-4484.
Coba de la Peña, T. and Brown, S. C. 2001. Flow cytometry. Pages 85-106 in: Plant Cell Biology: A Practical Approach, 2nd ed. C. Hawes and B. Satiat-Jeunemaître, eds. Oxford University Press, Oxford, U.K.

Conlon, I., and Raff, M. 1999. Size control in animal development. Cell 96: 235-244.

Fang, G., Hongtao, Y., and Kirschner, M. W. 1998. Direct binding of CDC20 protein family members activates the anaphase-promoting complex in mitosis and $\mathrm{G}_{1}$. Mol. Cell 2:163-171.

Favery, B., Complainville, A., Vinardell, J. M., Lecomte, P., Vaubert, D., Mergaert, P., Kondorosi, A., Kondorosi, E., Crespi, M., and Abad, P. 2002. The endosymbiosis-induced genes ENOD4O and $c \operatorname{cs} 52 \mathrm{~A}$ are involved in endoparasitic-nematode interactions in Medicago truncatula. Mol. Plant-Microbe Interact. 15:1008-1013.

Felstein, J. 1989. PHYLIP-Phylogeny Inference Package, version 3.2. Cladistics 5:164-166.

Foucher, F., and Kondorosi, E. 2000. Cell cycle regulation in the course of nodule organogenesis in Medicago. Plant Mol. Biol. 43:773-786.

Fred, E. B. 1908. Report of the Assistant Bacteriologist. Annual Report of the Virginia Agricultural Experiment Station 1908. Richmond, VA, U.S.A.

Galbraith, D. W., Harkins, K. R., Maddox, J. M., Ayres, N. M., Sharma, D. P., and Firoozabady, E. 1983. Rapid flow cytometric analysis of the cell cycle in intact plant tissues. Science 220:1049-1051.

González-Sama, A., Lucas, M. M., de Felipe, M. R., and Pueyo, J. J. 2004. An unusual infection mechanism and nodule morphogenesis in white lupin (Lupinus albus L.). New Phytol. 163:371-380.

Goormachtig, S., Valerio-Lepiniec, M., Szczyglowski, K., van Montagu, M., Holsters, M., and de Bruijn, F. J. 1995. Use of differential display to identify novel Sesbania rostrata genes enhanced by Azorhizobium caulinodans infection. Mol. Plant-Microbe Interact. 8:816-824.

Grafi, G. 1998. Cell cycle regulation of DNA replication: The endoreduplication perspective. Exp. Cell Res. 244:372-378.

Hirsch, A. M. 1992. Developmental biology of legume nodulation. New Phytol. 122:211-237.

Hoagland, D. R., and Arnon, D. I. 1938. The water culture method for growing plants without soil. California Agricultural Experiment Station Circ. No. 347. Sacramento, CA, U.S.A.

Iannetta, P. P. M., de Lorenzo, C., James, E. K., Fernández-Pascual, M. M., Sprent, J. I., Lucas, M. M., Witty, J. F., de Felipe, M. R., and Minchin, F. R. Oxygen diffusion in lupin nodules. I. Visualization of diffusion barrier operation. J. Exp. Bot. 44:1461-1467.

King, R. W., Peters, J. M., Tugendreich, S., Rolfe, M., Hieter, P., and Kirschner, M. W. 1995. A 20S complex containing CDC27 and CDC16 catalyzes the mitosis-specific conjugation of ubiquitin to cyclin B. Cell 81:279-288.

Kodama A. 1970. Cytological and morphological studies on the plant tumors I. Root nodules of some Leguminosae. J. Science Hiroshima Univ., Series B, Div. 2 13:223-260.

Koltai, H., Dhandaydham, M., Opperman, C., Thomas, J., and Bird, D. 2001. Overlapping plant signal transduction pathways induced by a parasitic nematode and a rhizobial endosymbiont. Mol. Plant-Microbe Interact. 14:1168-1177.

Kondorosi E., Roudier, F., and Gendreau, E. 2000. Plant cell-size control: Growing by ploidy? Curr. Opin. Plant Biol. 3:488-492.

Larkins, B. A., Dilkes, B. P., Dante, R. A., Coelho, C. M., Woo, Y. M., and Liu, Y. 2001. Investigating the hows and whys of DNA endoreduplication. J. Exp. Bot. 52:183-192.

Lotocka, B., Kopcinska, J., Gorecka, M., and Golinowski, W. 2000. Formation and abortion of root nodule primordia in Lupinus luteus L. Acta Biol. Cracov. 42:87-102.

Mckhann, H. I., and Hirsch, A. M. 1993. In situ localization of specific mRNAs in plant tissues. Pages 179-205 in: Methods in Plant Molecular Biology and Biotechnology. B. R Glick and J. E. Thompson, eds. CRC Press, Boca Raton, FL, U.S.A.

Newcomb, W., Sippell, D., and Peterson, R. L. 1979. The early morphogenesis of Glycine max and Pisum sativum root nodules. Can. J. Bot. 57:2603-2616.

Sambrook, J., Fritsch, E. F., and Maniatis, T. 1989. Molecular Cloning: A Laboratory Manual. 2nd ed. Cold Spring Harbor Laboratory Press, Cold Spring Harbor, NY, U.S.A.

Sprent, J. I. 2001. Nodulation in Legumes. Royal Botanic Gardens, Kew, London.

Tang, C., Robson, A. D., Dilworth, M. J., and Kuo, J. 1992. Microscopic evidence on how iron deficiency limits nodule initiation in Lupinus angustifolius L. New Phytol. 121:457-467.

Tang, C., Robson, A. D., and Dilworth, M. J. 1993. Anatomical and ultrastructural observations on infection of Lupinus angustifolius L. by Bradyrhizobium sp. J. Comput. Assist. Microsc. 5:47-51.

Tarayre, S., Vinardell, J. M., Cebolla, A., Kondorosi, A, and Kondorosi, E. 2004. Two classes of the Cdh1-type activators of the anaphase-promot- 
ing complex in plants: Novel functional domains and distinct regulation. Plant Cell 16:422-434.

Truchet, G. 1978. Sur l'état diploïde des cellules du méristème des nodules radiculaires des légumineuses. Annu. Sci. Nat. Bot., Paris 19:3-38.

Vinardell, J. M., Fedorova, E., Cebolla, A., Kevei, Z., Hovarth, G., Kelemen, Z., Tarayre, S., Roudier, F., Mergaert, P., Kondorosi, A., and Kondorosi, E. 2003. Endoreduplication mediated by the anaphase-promoting complex activator CCS52A is required for symbiotic cell differentiation in Medicago truncatula nodules. Plant Cell 15:2093-2105.
Vincent, J. M. 1970. A Manual for the Practical Study of Root-Nodule Bacteria: IBP Handbook No. 15. Blackwell Scientific Publications, Oxford.

\section{AUTHOR-RECOMMENDED INTERNET RESOURCE}

EMBO practical course on the new plant model system website: www.isv.cnrs-gif.fr/embo01/index.html 